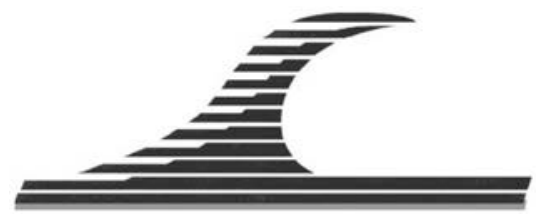

Revue Paralia, Volume 9 (2016) pp s02.1-s02.6

Keywords: Oued Isser, Mediterranean, Fine sediment, Minerals

clay, Facies, Particle size.

(C) Editions Paralia CFL

\title{
Distribution of fine sediment from the watershed of the oued Isser at its mouth in the Mediterranean Sea (Boumerdès, Algeria)
}

\section{Mohamed BOUHMADOUCHE ${ }^{1}$}

1. Laboratoire Géo-environnement, Faculté des Sciences de la Terre et de

l'Aménagement du Territoire. Université Houari Boumedienne, BP 32 El-Alia, Alger, Algérie.

mbouhamadouche@gmail.com

\begin{abstract}
:
The fluvial material of the oued Isser (Isser river) provided to the sea presents a high rate in fine particles originating from the watershed of the oued Isser. This material is rich in marl, limestone marl and shale formations, it is therefore not surprising that clays are abundant in the Bay of Zemmouri, since the oued Isser is the main vector of input conveying detrital sediments of the continental domain to the marine domain.

The granulometry of the lutitic fraction follows a gradual evolution from upstream ("La Traille" bridge) to the mouth with a $\mathrm{N}$ evolution index decreasing from sub-logarithmic to hyperbolic facies.

Oued Isser presents a low sandy percentage (9.89\% on average) hence a clay-silty facies. Clays consist essentially of kaolinite, in higher concentrations $(48.1 \%$ on average), illite (22.13\%), inter-stratified and other detrital sediments (18.33\%) and chlorite (11.4\%).
\end{abstract}

Translated version of a paper in French (DOI reference: http://dx.doi.org/10.5150/cmcm.2015.004), presented during the edition 3 of the Coastal and Maritime Mediterranean Conference,

(25-27 November 2015) in Ferrara, Italy.

Received 24 June 2015, accepted 11 December 2015, available online 01 March 2016

How to cite this paper:

BOUHMADOUCHE M. (2016). Distribution of fine sediment from the watershed of the oued Isser at its mouth in the Mediterranean Sea (Boumerdès, Algeria). Revue Paralia, Vol. 9, pp s02.1-s02.6.

DOI: http://dx.doi.org/10.5150/revue-paralia.2016.s02 


\section{Introduction}

This work is a contribution to a research theme oriented towards the determination of geomorphological and sedimentological geological phenomena in coastal zone. The study area is located on the Algerian coast $60 \mathrm{~km}$ east of Algiers.

This study found a significant decrease in fluvial inputs of the oued Isser and this decrease is most notable for the solid contributions this is mainly due to a drying of the climate having a direct influence on flows and therefore on the sedimentary input.

The other very important cause is the closing of this river by the construction of BeniAmran dam.

Nevertheless, the sedimentological study has identified the nature of the sediments transported by the oued Isser, their deposition mode and the various hydro-sedimentary mechanisms affecting the region.

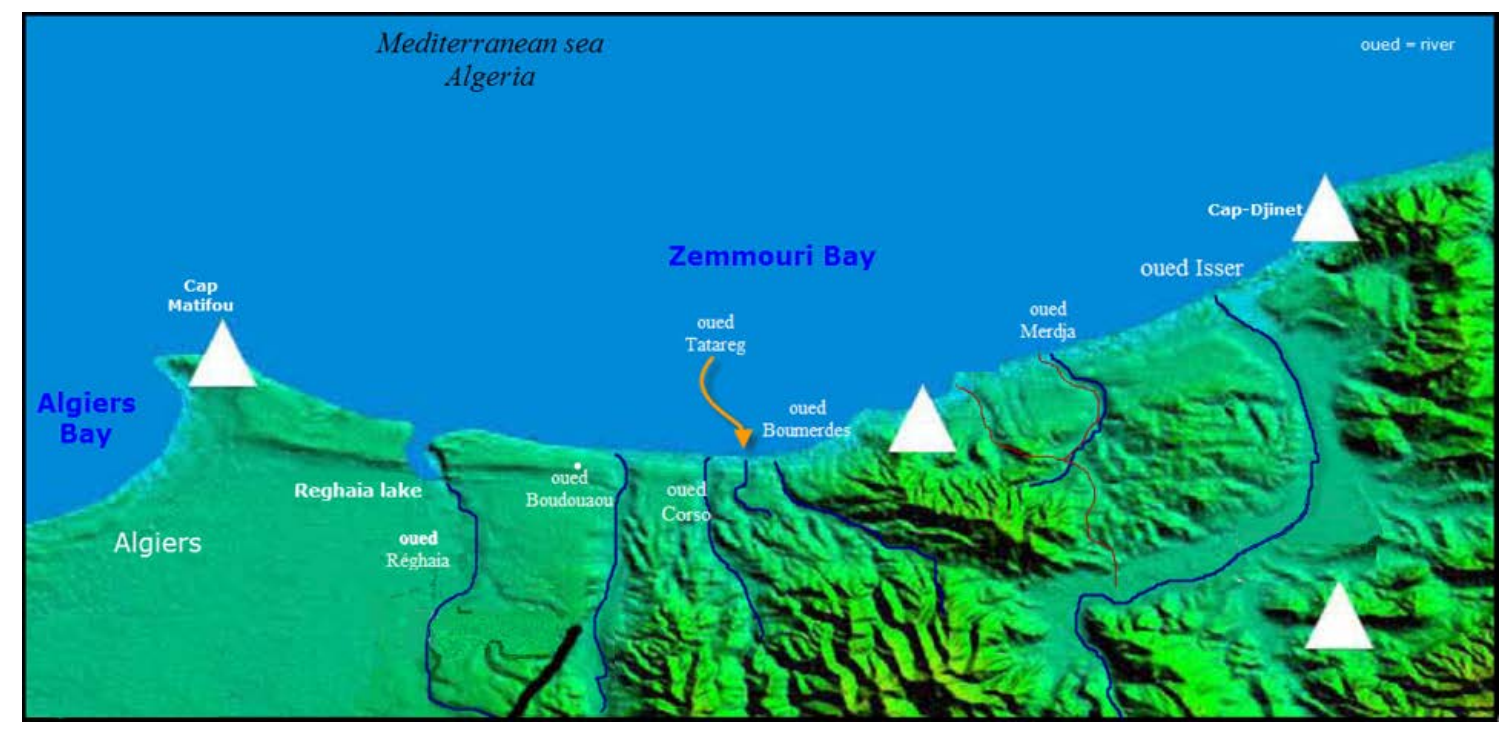

Figure 1. Location of the study area (oued = river).

\section{Methodology}

Sampling at sea was conducted using of a "Van Veen" type skip. Evolution indices of the sediments were calculated following a standard method (RIVIERE, 1977), while clay minerals have been determined by X-ray diffraction with a Phillips type PW 1710.

\section{Discussion}

\subsection{Sedimentology of the fine fraction}

We tried to determine the terms and conditions of transport and deposit of the lutitic fraction $(<40 \mu \mathrm{m})$ in and around (marine area) Oued Isser in order to detect a possible former prodelta or at least early siltation according to some authors (ALOÏSI et al., 1975). 
As such, we have taken targeted samples positioned as shown in Figure 2 and we noticed that the grading curve of the quoted samples show two facies: logarithmic and sub-logarithmic, the first located in the southwest, and other in the northeast (Figure 2). Parabolic and hyperbolic facies (deep sediment facies) inserted following a line joining sample A2 in the east to Zemmouri canyon (sample Z4, Figure 2). In the oued Isser we determined two facies: sub-logarithmic and hyperbolic.

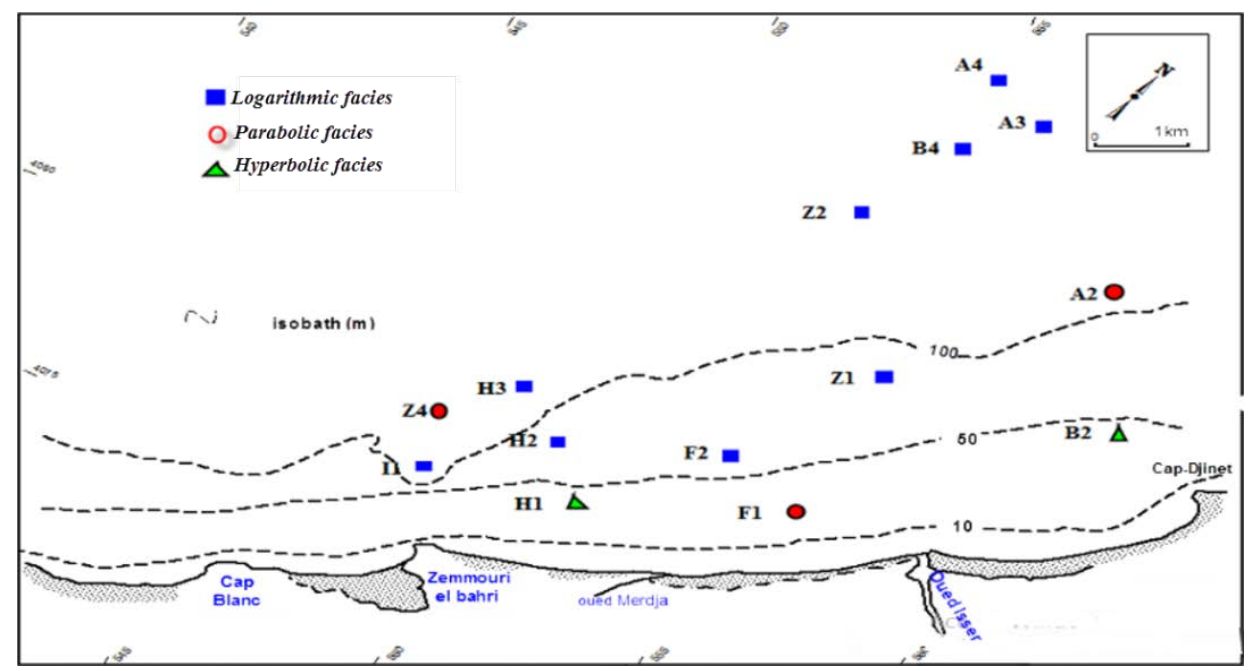

Figure 2. Marin area of the Isser: types of facies and evolution index.

\subsubsection{Fluvial field (oued Isser)}

The observed facies are:

a) sub-logarithmic facies: the representative curve of particle size distribution in semilogarithmic coordinates of the sample in "La Traille" bridge (OI1) appears as the ultimate evolution of sediments transported by currents and deposited by an excess of load when the speed decreases; in the same way, the sample located upstream from the mouth of oued Isser (O12) presents a sub-logarithmic facies that corresponds to a degraded suspension within the meaning of Passega (in RIVIERE, 1977); the deposit is made by excess of load when the energy decreases;

b) Hyperbolic facies: at the mouth, the facies is hyperbolic; the corresponding semilogarithmic cumulative curve shows a downwards concavity, its evolution is regular, showing a facies characteristic of the mudflats in the mouth of rivers (Figure 3, sample OI3).

\subsubsection{Marin field}

a) logarithmic or sub-logarithmic facies, these facies were observed for samples located at depths included between $40 \mathrm{~m}$ and $70 \mathrm{~m}$ in the western area of logarithmic facies (Figure. 2, samples Z1, F2, B2 and H1) and those of the continental slope between $-100 \mathrm{~m}$ and -200 m (sample H3), as well as at $400 \mathrm{~m}$ depth (sample A4); 
b) Hyperbolic facies, the mean evolution index of particle size distribution is less than zero, particle size facies is hyperbolic these curves were observed in the samples: Z4, A2, and F1;

c) Parabolic facies, evolution index is greater than zero, particle size facies is thus parabolic (Figure 2, B2 and M1).

All these samples detailed in Table 1.

\subsection{Distribution of the clay mineral fraction $(<2 \mu \mathrm{m})$}

\subsubsection{Marin field}

Clay minerals are conventionally used as hydrodynamic markers (ALOÏSI, 1986).

The clay fraction consists of clay minerals such as, kaolinite, illite, chlorite, organized according to a descending order of magnitude.

The distribution of these minerals on the continental shelf East of Algiers (Bay of Zemmouri) is highly significant, given the presence of two important factors: the contributions of the oued Isser draining Neogene formations from its watershed and the proximity of the volcanic massif of Cap Djinet.

\subsubsection{Fluvial field}

The distribution of clays in the watershed of oued Isser is as following:

a) kaolinite is the most common clay mineral in soils of temperate countries (CAILLERE et al., 1982). It presents little variable contents in the oued Isser (48\% on average), it is the dominant clay mineral;

b) illite: its distribution in the bed of the oued Isser (Figure 3) is homogeneous, $22 \%$ on average, such as kaolinite, illite is found also under humid climate during the decomposition of feldspathic acidic rocks (CAILLERE et al., 1982);

c) chlorite is less common than illite and kaolinite, it presents levels of $13 \%$ (OI2) These levels decrease significantly at the level of the mouth marking the value of 7.9\% (OI1; Figure 3). Chlorite is a typical metamorphic mineral; it could come from all existing metamorphic formations in the basin of the Isser, among other the schistcrystalline massif of "Krachna" which includes chlorite schists. 


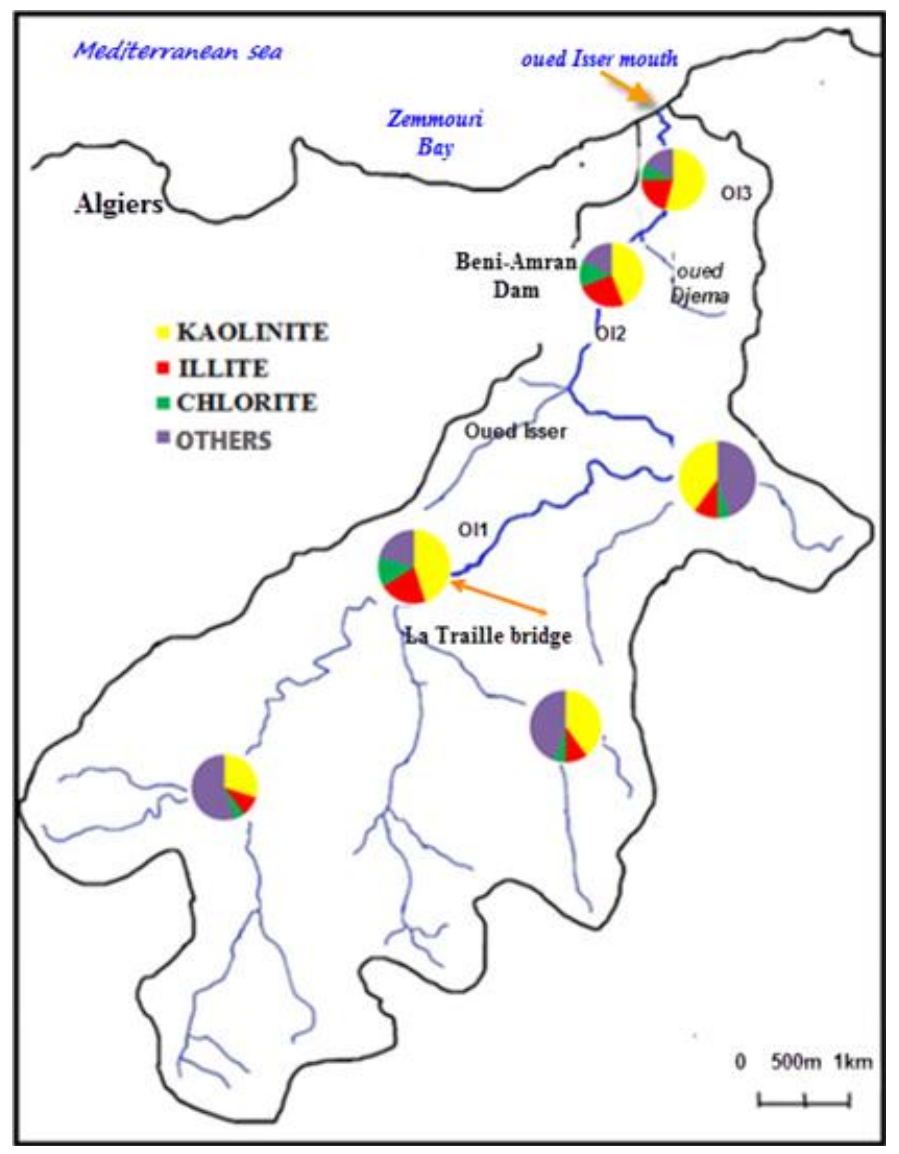

Figure 3. Proportions of clay minerals in the oued Isser and its watershed.

\section{Conclusion}

Our study highlights the dominance of kaolinite in clay procession, the results confirm the work of CHAMLEY (1971) and LECLAIRE (1972). The average percentages of clay minerals are the following: kaolinite $42.89 \%$, illite $23.66 \%$, chlorite $17.83 \%$ and the inter-stratified $15.61 \%$. (Table 1 )

The existence of early siltation in the front of the oued Isser could be reasoned by the following factors:

- Very high percentages in lutitic fraction $(<40 \mu \mathrm{m})$ (between $75 \%$ and $90 \%)$ at low depths, distributed in the vicinity of the oued Isser,

- High rates in fine silts in the front of the oued Isser (Figure 3 and Table 1), with levels above $30 \%$,

- Hyperbolics facies concerning only a single sample (Fl) close to the mouth and located at $-20 \mathrm{~m}$ depth of the West Coast (Table 1). Especially for the Algerian margin, clay minerals allow to highlight the climate change that occurred in North Africa around -7500 to -7000 years BP from a change from illite to kaolinite dominance (PAUC, 1991). 
Table 1. Percentage of the different size classes and facies types.

\begin{tabular}{llllllll}
\hline Sample & $\begin{array}{l}\text { Depth } \\
(\mathrm{m})\end{array}$ & $\begin{array}{l}\text { Lutites } \\
(\%)\end{array}$ & $\begin{array}{l}\text { Coarse } \\
\text { silts }(\%)\end{array}$ & $\begin{array}{l}\text { Fine } \\
\text { silts }(\%)\end{array}$ & $\begin{array}{l}\text { Clays } \\
(\%) \\
40-10 \mu m\end{array}$ & $\begin{array}{l}\text { Evolution } \\
\text { Index }\end{array}$ & Facies Type \\
& & 72.83 & 4.1 & 23.9 & 60 & -0.04 & Sublogarithmic \\
\hline OI 1 & - & 98.25 & 3.2 & 29 & 55 & -0.05 & Sublogarithmic \\
OI 2 & - & 32 & 60 & -0.15 & Hyperbolic \\
OI 3 & - & 99.25 & 3 & 32 & -0.06 & Sublogarithmic \\
Z1 & 57 & 92.52 & 5.5 & 40 & 39 & -13 & Sublogarithmic \\
Z2 & 200 & 31.14 & 6.5 & 27.6 & 56 & 0.13 & Hyperbolic \\
Z3 & 300 & 98.45 & 0 & 19 & 78 & -0.11 & Hyperbolic \\
A2 & 63 & 97.12 & 1 & 34.2 & 60 & -0.08 & Sublogarithmic \\
A3 & 95 & 39.26 & 5 & 28.7 & 55 & -0.03 & Logarithmic \\
A4 & 400 & 99.44 & 6 & 38.4 & 54.5 & 0.00 & Hyperbolic \\
H1 & 22.5 & 19.18 & 8 & 20 & 58 & -1.15 & Sublogarithmic \\
H2 & 72.5 & 91.59 & 9 & 25 & 47 & -0.01 & Logarithmic \\
H3 & 160 & 96.61 & 4.5 & 30 & 55.6 & 0.00 & Parabolic \\
B2 & 63 & 40.93 & 3 & 24.4 & 60 & 0.17 & Sublogarithmic \\
B4 & 200 & 83.56 & 4 & 28 & 59 & 0.04 & Hyperbolic \\
F1 & 20 & 61.87 & 7.5 & 32 & 42 & -0.10 & Sublogarithmic \\
F2 & 64 & 87.44 & 6.5 & 28.2 & 48 & -0.07 & Sublogarithmic \\
I1 & 40 & 34.62 & 5 & 28 & 54 & -0.02 & \\
\hline
\end{tabular}

\section{References}

ALOÏSI J.-C. (1986) Sur un modèle de sédimentation deltaïque. Contribution à l'étude des marges passives. Thèse Université de Perpignan.

ALOÏSI J.C., MONACO. A., PAUC H. (1975). Mécanisme de la formation des prodeltas dans le Golfe du Lion. Bull. Inst. Geol. Bassin Aquitaine., Vol. 18, pp 3-12.

CAILLERE S., HENIN S., RAUTUREAU M. (1982). Minéralogie des argiles. Ed. Masson, Paris, Tomes 1 et 2 (184 p. et 189 p.).

CHAMLEY H. (1971). Recherche sur la sédimentation argileuse en Méditerranée. Thèse Université de Marseille, 401 p.

LECLAIRE L. (1972). La sédimentation holocène sur le versant méridional du bassin Algéro-Baléares. Thèse doctorat d'état, Mémoires du muséum national d'histoire naturelle, Paris, 391 p.

PAUC H. (1991). La nature minéralogique des apports en suspension sur la marge algérienne et leurs relations avec les sédiments. $3^{\text {ème }}$ Congrès Français de Sedimentologie, Brest, 18-20 novembre 1991.

RIVIERE A. (1977). Méthodes granulométriques : techniques et interprétations. Ed. Masson, Paris, 170 p. 